\title{
HUKUM ISLAM DAN SENGKETA EKONOMI SYARI'AH (Telaah UU N0. 3/2006 dan UU N0. 50/2009)
}

\author{
Abdi Wijaya \\ Fakultas Syariah dan Hukum Universitas Islam Negeri Alauddin Makassar
}

\begin{abstract}
A sharia economic dispute arose in the absence of clear rules governing it. Or, in other words, the existence of legal ambiguity. In practice, the sharia economic dispute raises a question mark whether it is resolved in the District Court or the Religious Courts. With the birth of Law no. 3/2006 and Law No. 50/2009 have authorized the Religious Courts to resolve the Sharia economic dispute.
\end{abstract}

\section{Keywords:}

Disputes on Sharia Economy, Law

\begin{abstract}
Abstrak
Sengketa ekonomi syariah lahir karena tidak adanya peraturan yang jelas dalam mengaturnya. Atau, dengan kata lain, adanya ambiguitas hukum. Dalam praktiknya, sengketa ekonomi syariah, menimbulkan tanda tanya apakah diselesaikan di Pengadilan Negeri atau Pengadilan Agama. Dengan lahirnya UU No. 3/2006 dan UU No.50/2009 telah memberikan wewenang kepada Pengadilan Agama untuk menyelesaikan sengketa ekonomi Syariah.
\end{abstract}

Kata Kunci:

Sengketa Ekonomi Syariah, UU

\section{A. PENDAHULUAN}

$\mathrm{I}$

slam sebagai agama yang diturunkan oleh Allah swt. kepada Nabi Muhammad swa. membawa misi yang penuh dengan kemaslahatan bagi manusia. Hal tersebut dapat dilihat dan dibaca dalam Alquran dan Sunnah.

Islam dapat dikategorisasikan ke dalam tiga konfigurasi yang saling memiliki hubungan yang harmonis. Ketiga bentiuk konfigurasi tersebut adalah aqidah, ibadah dan muamalah.Tiga konfigurasi ini yang harus dilaksanakanoleh manusia dalam menempuh kehidupannya.

Dari ketiga bentuk konfigurasi di atas, yang terakhir (muamalah) merupakan wilyah yang paling dominan dan memiliki andil yang sangat signifikan dalam interaksi antar sesama manusia. Wilayah muamalah memasuki bidang perkawinan, waris, wasiat, hibah, waqaf, zakat infaq shadaqah dan ekonomi. 
Dalam bidang ekonomi, sebagaimana juga dalam bidang-bidang yang lain tidak luput dari kajian Islam yang bertujuan agar manusia berada di jalan lurus. Namun, dalam melakoni aktifitas ekonomi, para pelaku ekonomi kadang-kadang menemui dan mengalami konflik, perseturuan dan sengketa.

Dalam sengketa yang terjadi antar sesama praktisi ekonomi sering menimbulkan masalah yang kontra produktif, sehingga perlu dibuatkan regulasi yang mengatur mengenai hal tersebut. Dengan demikian, segala persoalan dapat diselesaikan dengan baik dan meminimalisir terjadinya konflik.

\section{B. PEMBAHASAN}

\section{Eksistensi Ekonomi Syari'ah}

Ekonomi syari'ah sebagai sebuah sistem, saat ini merupakan pilihan dalam melakukan kegiatan ekonomi. Sebagai sebuah sistem sebagaimana layaknya dengan sistem-sistem ekonomi yang ada dewasa ini (kapitalisme dan sosialisme) didalamnya mengusung seperangkat nilai, asas, dan prinsip yang berfungsi sebagai pedoman dan pengarah, bahkan pengontrol yang tidak boleh ada penyimpangan yang kontradektif dengan nilai-nilai tersebut.

A.M. Saefuddin menyatakan bahwa sistem ekonomi tertentu haruslah tersusun dari seperangkat nilai-nilai yang dapat membangun kerangka organisasi kegiatan ekonomi menurut kerangka tertentu. Perangkat nilai-nilai ini di satu pihak akan berdasarkan pandangan filsafat tentang kegiatan ekonomi, dan di pihak lain interaksi nilai-nilai ini membentuk perangkat nilai dasar dan nilai instrumental bagi kegiatan ekonomi yang dikehendaki oleh sistem. ${ }^{1}$ Demikian pula halnya dengan ekonomi syariah juga memiliki seperangkat nilai, asas dan prinsip sekaligus merupakan visi dan misi yang diembannya guna memfasilitasi manusia dalam aktivitasnya mendapatkan kesejahteraan lahir dan batin.

Relevan dengan pembahasan mengenai nilai-nilai yang diusung dalam sistem ekonomi syariah, secara filosofis perlu dikemukakan terlebih dahulu bagaimana sistem nilai dan pengejawantahannya sebagai ciri pembeda dengan sistem-sistem yang lainnya. Hal ini mendasar untuk dilakukan lebih awal untuk menjaga sistematisasi dan konsistensi alur analisis dalam penelitian ini, yang memang menekankan pada aktualisasi dan implementasi nilai-nilai ekonomi syariah secara komperehensif. Dengan cara demikian, akan terlihat nantinya sejumlah nilai yang menarik dan perlu untuk dikaji serta secara praksis diharapkan akan lebih membumi dan mendatangkan kemaslahatan bagi seluruh makhluk khususnya manusia.

Seorang pemikir ekonomi Islam generasi pertama di Indonesia, A.M. Saefuddin mengemukakan bahwa sebuah nilai atau nilai-nilai merupakan seperangkat keyakinan perasaan (sentimen) dan identitas yang memberikan corak khusus kepada pola pemikiran, keterikatan dan prilaku dari individu, masyarakat maupun bangsa. ${ }^{2}$

\footnotetext{
${ }^{1}$ A.M. Saefuddin, Studi Nilai-Nilai Sistem Ekonomi Islam (Cet. I; Jakarta: Media Da'wah, 1984), h. 14

${ }^{2}$ A.M. Saefuddin, Ontologi Sosial Ekonomi (Makassar: UMI Press, 1988), h., 4.
} 
Pada prinsipnya, sebuah nilai selalu dimaknakan secara positif diposisikan pada level tertinggi dan bersifat abstrak, masih memerlukan upaya interpretasi dan konkretisasi agar dapat diaplikasikan.

Ekonomi Syari'ah khususnya perbankan syariah bukan hanya milik praktisi ekonomi syariah, melainkan semua umat Islam bahkan diluar umat Islam pun diberikan "hak" untuk berpartisipasi minimal ada transparansi di dalamnya, agar tidak terjadi kezdaliman, unsur-unsur keharaman sedikitpun tidak boleh ada di dalamnya. Amar ma' ruf nahi mungkar betul-betul harus terjelma dalam sistem ini.

Saat ini, kehadiran ekonomi syari'ah dinilai sangat responsif, selain sebagai alternatif di antara siatem kapitalisme dan sosialisme, juga mengusung misi ilahiyah yang sanga sesuai dengan nilai-nilai humanistik, bukan itu saja, tetapi juga membawa nilai-nilai tazkiyah jauh dari hal-hal yang diharamkan, baik terhadap objek, proses maupun terhadap out put-nya, semua yang bermuara dalam kerangka mendapatkan ridha Allah swt.. Dan secara realistis menunjukkan bahwa sistem ini memiliki nilai kompetitif mampu menghantarkan bangsa Indonesia keluar dari krisis ekonomi yang simultan.

Ekonomi syari'ah, menurut Mohammad Nejatullah Shiddiq tidak terlepas dari pemikiran ekonomi yang telah berusia setua dengan Islam itu sendiri. Sepanjang 14 abad yang silam, sejarah Islam telah menjelaskan penemuan studi yang berkelanjutan tentang isu ekonomi dalam pandanga syari'ah. Sebagian besar diskursus ini hanya terkubur dalam literatur tafsir Alquran, syarah hadis, dasardasar hukum, ushul fighi dan hukum fighi. Belum terdapat usaha-usaha sistematis untuk mengkaji lebih dalam lagi materi-materi itu agar menjadi lebih aplikatif. ${ }^{3}$

Pernyataan di atas, merupakan keprihatinan dari seorang pakar ekonomi syari'ah beberapa puluh tahun yang lalu, namun kini pernyataan tersebut sudah tidak relevan lagi dengan merebaknya kajian-kajian ekonomi syariah dan pada tataran praktisnya pun bermunculan lembaga-lembaga ekonomi syariah di seantero dunia.

Khusus di Indonesia, pada tahun 1970-an gerakan Islam secara nasional memasuki lapangan baru di bidang ekonomi dengan memperkenalkan sebuah sistem ekonomi Islam di antara sistem-sistem ekonomi yang ada, yaitu sebagai alternatif dari sistem kapitalisme dan sosialisme. wacana sistem ekonomi Islam diawali dengan konsep ekonomi dan bisnis non riba. ${ }^{4}$ Gerakan ini sama saja dengan mereka-mereka yang memperjuangkan tegaknya syariat Islam di bidang politik dan hukum di tanah air ketika itu. Sejumlah tokoh yang terlibat dalam wacana ekonomi Islam kala itu antara lain, A.M.Saefuddin, Karnaen Perwataatmaja, M. Amin Aziz, Muhammad Syafii Antonio, dan lainnya. Puncak dari perjuangan dalam mewacanakan ekonomi syariah itu pada tahun 1992 ditandai dengan didirikannya

\footnotetext{
${ }^{3}$ Adiwarman Karim, Ekonomi Mikro Islam (Jakarta: Rajawali Press, 2002), h. 3.

${ }^{4}$ Lihat Suhrawardi K Lubis, Hukum Ekonomi Islam, edisi I (Cet. II; Jakarta: Sinar Grafika, 2000), h., 47.
} 
lembaga keuangan syariah pertama, yaitu Bank Muamalat Indonesia (BMI), berkat prakarsa MUI, ICMI dan pemerintah Orde Baru. ${ }^{5}$

Dalam konteks ekonomi Islam, penggunaan istilah juga tidak seragam, misalnya di Indonesia umumnya digunakan Ekonomi syariah sementara di dunia lainnya yang lebih populer digunakan adalah Ekonomi Islam. Menurut Mustafa E. Nasution istilah ekonomi syariah hanya ditemukan penggunaannya di Indonesia sehubungan dengan pendirian Bank Syariah pertama pada tahun 1992. ${ }^{6}$ Sedangkan di dunia internasional istilah itu tidak digunakan, melainkan Bank Islam. ${ }^{7}$ Dengan demikian ekonomi Islam tidak hanya berkonotasi bank tanpa bunga, akan tetapi meliputi seluruh aspek kegiatan ekonomi.

Penggunaan istilah syariah dan Islam untuk menunjukkan konsepsi dan institusi ekonomi berbasis ajaran Islam tidak terlalu urgen yang dipermasalahkan, karena keduanya mengarah kepada sasaran yang sama, yaitu untuk menunjukkan sebuah sistem ekonomi yang berbasis pada syariat Islam. Namun, dalam konteks Indonesia hal itu memiliki latar belakang tersendiri yang menarik untuk disimak, ketika wacana ekonomi Islam mendapat tanggapan luas bagi masyarakat bersamaan dengan itu pula suasana fhobia terhadap Islam menggelora, banyak kalangan yang sengaja membangun opini dengan menonjolkan gerakan-gerakan separatis Islam seperti DI, TII, dan Gerakan Kahar Muzakkar, sehingga kesan dari kata Islam selalu diarahkan kesana. Pertimbangan historis inilah yang menyebabkan penggunaan ekonomi Islam menjadi tidak populer, melainkan dengan ekonomi syariah.

Penggunaan istilah ekonomi syariah, Dawam Raharjo menjelaskan bahwa apa yang dimaksudkan dengan ekonomi syariah tidak identik dengan syariat itu sendiri, syari'at dalam pengertian Muhammad Said al-Asmawi (ahli Hukum Islam Mesir), adalah wahyu Tuhan dan Sunnah Rasul yang pengertiannya sama dengan tharieq, sabil, dan manhaj, yaitu jalan (way). Syariat dalam pengertian ini masih memerlukan penjelasan dan interpretasi, setelah itu syariat mengalami proses rasionalisasi melalui metode ilmiah (ijtihad), hasilnya melahirkan konsep bank syariah. Sementara istilah bank syariah itu sendiri khas Indonesia dan tidak dijumpai di negara lain. ${ }^{8}$

Di negara lain, lembaga itu dikenal bank Islam (Islamic Bank). Di Indonesia, bank Islam telah mengalami kontekstualisasi sehingga bernama Bank Syariah, berkaitan dengan tradisi perjuangan menegakkan syariat Islam yang muncul di sekitar awal berdirinya republik ini dan tercantum pula dalam naskah Piagam Jakarta.

${ }^{5}$ Dawam Raharjo, Ekonomi Islam: Suatu Kajian Kontemporer (Jakarta: Gema Insani Press, 2003), h., xvii.

${ }^{6}$ Syaiful Bahri, Ekonomi Syari'ah dalam Sorotan (Jakarta: Permodalan Nasional Madani, 2003), h., 28.

${ }^{7}$ Muhammad Syafi'Antonio, Bank Syari'ah dari Teori ke Praktek (Cet. I; Jakarta: Gema Insani Press, 2001), h., 19.

${ }^{8}$ Dawam Raharjo, Ekonomi Islam: Suatu Kajian Kontemporer, h. 3. 
Pandangan mengenai eksistensi ekonomi Islam, Afzalur Rahman melihatnya sebagai sebuah sistem dan berbeda di antara sistem ekonomi kapitalisme dan sosialisme. Ekonomi Islam memiliki kebaikan-kebaikan yang terdapat pada kedua sistem sekuler tersebut, namun terbebas dari kelemahan-kelemahan yang terdapat dari kedua sistem itu. ${ }^{9}$ Melalui ekonomi Islam tidak hanya menyiapkan individuindividu sejumlah kemudahan dalam bekerjasama berlandaskan syariah tetapi juga memberikan pendidikan moral yang tinggi dalam kehidupan.

\section{Hakikat Ekonomi Syariah}

Ekonomi Islam atau ekonomi syariah secara anatomis, merupakan salah satu bidang dalam syariat Islam, yakni bidang muamalah. Bidang muamalah memiliki cakupan yang begitu luas mencakup segala hubungan interaktif semua makhluk Tuhan di bumi yang menempatkan manusia sebagai aktor utama (khalifah). Bidang ekonomi merupakan salah satu di antaranya yang khusus membahas interaksional antara manusia dengan sesamanya yang berkaitan dengan materi dan jasa dalam rangka kesejahteraan mereka di bawah tuntunan syariah.

Secara filosofis, Monzer Kahf mengemukakan bahwa pada umumnya ekonomi didefinisikan sebagai kajian tentang perilaku manusia dalam hubungannya dengan pemanfaatan sumber-sumber produksi yang langka untuk menghasilkan barangbarang dan jasa-jasa serta mendistribusikannya untuk dikonsumsi. ${ }^{10}$

Relevan dengan definisi tersebut, ajaran Islam menekankan bahwa kegiatankegiatan ekonomi manusia merupakan salah satu perwujudan dari pelaksanaan tanggungjawabnya sebagai khalifah di bumi agar kehidupan tetap terjaga keseimbangannya. ${ }^{11}$ Melalui kegiatan ekonomi keseimbangan menjadi penting karena disinilah esensi syariat Islam berperan di dalamnya, berupa keseimbangan dalam mengejar kesejahteraan dunia demikian pula untuk di akhirat. ${ }^{12}$ Ketidakseimbangan akan mewujud jika pertimbangan materi lebih mendominasi di dalamnya seperti praktek ekonomi sekuler.

Syed Nawab Haider Naqvi mengemukakan bahwa sistem ekonomi syari'ah merupakan sistem buatan manusia juga sebagaimana sistem ekonomi lain dan keberhasilannya juga akan ditentkuan oleh pegujian daya hidupnya yang bisa diterima secara universal. Pandangan ini lebih menekankan pada aspek empirik dari ekonomi syaria'ah yang dapat diuji baik secara teoritik maupun secara praktis ${ }^{13}$.

Dengan demikian, ekonomi syari'ah selayaknya dikembangkan secara simultan dalam dua tingkat yaitu: pertama, harus mereflesikan pemahaman pengetahuan yang jelas terhadap esensi nilai etik dasar Islam sebagai implementasi hakikat di

\footnotetext{
${ }^{9}$ Afzalur Rahman, Doktin Ekonomi Islam (Yogyakarta: Simpul Rekacitra, 1995), h., 10.

${ }^{10}$ Monzer Kahf, Ekonomi Islam: Telaah Analitik Terhadap Fungsi Sistem Ekonomi Islam (Yogyakarta: Pustaka Pelajar, 2005), h., 4.

${ }^{11}$ Q.S.al-Baqarah(2):30.

12 Ridwan Mas'ud dan Muhammad, Zakat dan Kemiskinan: Instrumen Pemberdayaan Ummat (Yogyakarta: UII Press, 2005), h., xiii.

${ }^{13}$ Syed Nawab Haidir Naqvi, Menggagas Ilmu Ekonomi Islam (Yogyakarta: Pustaka Pelajar, 2003), h., 4.
} 
dalamnya dan yang kedua, dengan menggunakan masyarakat muslim couter-part dunia riil ekonomi Islam, maka serangkaian refresentasi hipotetik perilaku muslim terlebih dahulu ditetapkan selanjutnya dibuktikan secara emperik.

Berkaitan dengan hakikat ekonomi syari'ah, Umar Chapra berpandangan bahwa ilmu yang memberikan kontribusi langsung atau tidak langsung terhadap realisasi kesejahteraan manusia tetap berkonsentrasi pada aspek alokasi dan distribusi sumber-sumber daya dengan tujuan utama untuk merealisasikan maqasid syari'ah. Ilmu ekonomi syari'ah pada prinsipnya sama dengan ekonomi konvensional, akan tetapi, yang mendasar perbedaannya adalah pada pertimbangan sosial kemanusiaan sesuai dengan komitmen syariat Islam, sementara pada ekonomi konvensional hanya bermuara pada upaya pemenuhan kebutuhan materilal seperti halnya dalam ekonomi kapitalis. ${ }^{14}$

Eksistensi ekonomi syari'ah yang didasarkan pada ilmu ekonomi konvensional sebagaimana yang diberikan oleh Umar Chapra dan Naqvi sesuai dengan prinsip muamalah dalam hukum Islam bahwa pada prinsipnya segala sesuatu boleh saja diterima sepanjang belum ada ketentuan yang tegas melarangnya. Ilmu ekonomi konvensional merupakan fenomena kehidupan bahkan telah menjadi bagian dari kehidupan. Jika fenomena itu mendatangkan manfaat, maka hukumnya boleh dan dapat diterima, akan tetapi jika fenomene itu mengdatangkan mudharat, maka ia harus ditinggalkan. Secara substantif, materi-materi yang tersaji dalam ilmu ekonomoi konvensional dapat diterima sepanjang tidak bertentangan dengan nilainilai ekonomi syaria'ah

\section{Eksistensi regulasi (UU N0. 3/2006 dan UU N0. 50/2009) terhadap kegiatan ekonomi syari'ah}

Perkembangan lembaga-lembaga keuangan syariah tumbuh pesat di Indonesia, seperti perbankan syariah, asuransi syariah, pasar modal dengan instrumennya obligasi dan reksadana syariah, pegadaian syariah, dana pensiun syariah, lembaga keuangan mikro syariah, dan sebagainya. Menurut data Bank Indonesia (Mei 2005), jumlah nasabah /deposan perbankan syariah lebih dari 2 juta orang, sedangkan jumlah nasabah pembiayaan sekitar 300.000an orang. Data itu belum termasuk nasabah asuransi, pegadaian, pasar modal dan dana pensiun syariah. Juga belum termasuk nasabah Baitul Mal wat Tamwil yang mencapai dari 3 juta orang. ${ }^{15}$

Dengan banyaknya masyarakat Indonesia yang beraktivitas dalam ekonomi syariah, maka sangat dimungkinkan terjadinya sengketa hukum di bidang ekonomi syariah. Jika terjadi perselisihan antara para pihak, selama ini kasusnya selama ini diselesaikan di Pengadilan Umum, atau Badan Arbitrase Syariah, bukan Pengadilan Agama. Artinya, sebelum keluarnya UU No 3/2006, tentang Peradilan Agama perkara-perkara yang menyangkut peralihan harta atau kebendaan dan perjanjian

\footnotetext{
${ }^{14}$ Umar Chapra, Masa Depan Ilmu Ekonomi: Sebuah Tinjauan Islam (Jakarta: Gema Insani Press, 2001), h., 99 .

${ }^{15}$ Agustianto, Peradilan dan Sengketa Ekonomi Syari'ah, h. 1. http :www. Nuriah. Com. (15 Juni 2015).
} 
yang bersifat bisnis masih menjadi kewenangan Pengadilan Negeri, dikarenakan kewenangan Pengadilan Agama masih sangat terbatas. Pasal 49, UU No. 7 Tahun 1989 tentang Peradilan Agama hanya menentukan bidang-bidang tertentu saja yang menjadi kewenangan (kompetensi absolut) Pengadilan Agama, yaitu bidang: Perkawinan, Kewarisan (yang meliputi juga wasiat dan hibah) dan Wakaf dan Shadaqah. Karena itulah UU Nomor 7/1989 diamandemen pemerintah dan DPR dengan Undang-Undang yang baru yakni UU No 3/2006. Dalam pertimbangan amandemen Undang-Undang tersebut disebutkan bahwa Peradilan Agama dalam Undang-Undang Nomor 7 Tahun 1989 sudah tidak sesuai lagi dengan perkembangan ${ }^{16}$ kebutuhan hukum masyarakat, karena itu perlu lakukan amandemen.

Pada pasal 49 point i disebutkan dengan jelas bahwa Pengadilan Agama bertugas dan berwenang memeriksa, memutus dan menyelesaikan perkara di tingkat pertama antara ortang -orang yang beragama Islam di bidang ekonomi syariah. Dalam penjelasan UU tersebut disebutkan bahwa yang dimaksud dengan ekonomi syariah adalah perbuatan atau kegiatan usaha yang dilaksanakan menurut prinsip syari'ah, antara lain meliputi : Bank syariah, Lembaga keuangan mikro syari'ah,asuransi syari'ah, reksadana syari'ah, Obligasi syariah dan surat berharga berjangka menengah syariah, Pembiayaan syari'ah, pegadaian syari'ah, Amandemen ini membawa implikasi baru dalam sejarah hukum ekonomi di Indonesia. Selama ini, wewenang untuk menangani perselisihan atau sengketa dalam bidang ekonomi syariah diselesaikan di Pengadilan Negeri yang notabene belum bisa dianggap sebagai hukum syari'ah.

Pengadilan Negeri bisa disebut sebagai Pengadilan konvensional. Maka sangat aneh, jika masalah syariah diselesaikan secara konvensional, bukan secara syariah. Dalam prakteknya, sebelum amandemen UU No 7/1989 ini, penegakan hukum kontrak bisnis di lembaga-lembaga keuangan syariah tersebut mengacu pada ketentuan KUH Perdata yang merupakan terjemahan dari Burgerlijk Wetboek (BW), kitab Undang-undang hukum sipil Belanda yang dikonkordansi keberlakuannya di tanah Jajahan Hindia Belanda sejak tahun 1854 ini, sehingga konsep perikatan dalam Hukum Islam tidak lagi berfungsi dalam praktek formalitas hukum di masyarakat, tetapi yang berlaku adalah BW.Secara historis, norma-norma yang bersumber dari hukum Islam di bidang perikatan (transaksi) ini telah lama memudar dari perangkat hukum yang ada akibat politik Penjajah yang secara sistematis mengikis keberlakuan hukum Islam di tanah jajahannya, Hindia Belanda

Akibatnya, lembaga perbankan maupun di lembaga-lembaga keuangan lainnya, sangat terbiasa menerapkan ketentuan Buku Ke tiga BW (Burgerlijk Wetboek) yang sudah diterjemahkan. Sehingga untuk memulai suatu transaksi secara syariah tanpa pedoman teknis yang jelas akan sulit sekali dilakukan.

\footnotetext{
${ }^{16}$ Lihat Prides, Kompilasi Perundang-undangan tentang Ekonomi Syariah (Cet. I; Ciputat: Gaung Persada Press, 2008), h., 132.
} 
Amandemen ini memang dirasakan sangat penting, mengingat perkembangan lembaga keuangan syari'ah bergerak cepat, seperti perbankan syari'ah, asuransi syari'ah, pasar modal syari'ah, lembaga keuangan mikro syariah (BMT), pergadaian syari'ah, dsb. Selama ini, banyak kasus sengketa ditangani oleh Basan Arbitrase Syariah Nasioal (Basyarnas), sesuai dengan akad di lembaga keuangan syariah. Nasabah dan lembaga perbankan secara "terpaksa" harus memilih lembaga Basyarnas untuk menyelesaikannya. Setiap draft kontrak syariah telah memuat klausul Basyarnas. Keharusan ke Basyarnas karena belum dikeluarkannya UU No3/2007.

Akan tetapi, setelah keluarnya Undang-Undang tersebut, harus dibuka peluang seluas-luasnya kepada Pengadilan Agama untuk mengadilinya, sehingga tidak menjadi monopoli Basyarnas.Selain itu, sering pula ditemukan redaksi akad yang membuka dualisme hukum yang sangat menyesatkan. Banyak bank-bank yang syariah yang menyebutkan dalam akadnya, bahwa jika terjadi perselisihan akan diselesaikan oleh lembaga arbitrase syariah atau Pengadilan Negeri. Hal ini menyesatkan, karena jika para pihak sudah menentukan dan memilih lembaga arbitrase, maka sudah tertutup peluang kepada Pengadilan Negeri. Pilihan tersebut harus tegas, apakah arbitrase atau pengadilan Negeri. Jika para pihak memilih pengadilan Negeri, hal inipun tidak tepat, tidak relevan dan jelas tidak sesuai syariah.

Dengan keluarnya UU No 3/2006, kasus sengketa ekonomi syariah harus diselesaikan di Pengadilan Agama, kecuali para pihak sepakat diselesaikan melalui lembaga arbitrase. Satu hal lagi yang menjadi catatan penting adalah masalah eksekusi. Selama ini eksekusi keputusan arbitrase dilakukan oleh Pengadilan Negeri, bukan Pengadilan Agama (Syariah). Ketentuan ini sesuai dengan Undang-Undang Arbitrase No 30 Tahun 1999. Realita ini seharusnya diubah, pasca keluarnya UU No 3/2006. Dengan kata lain, Undang-Undang arbitrase harus diamandemen.

Lahirnya UU No 3 Tahun 2006 ini juga membawa implikasi besar bagi seluruh redaksi akad di lembaga perbankan dan keuangan syari' ah saat ini. Selama ini dalam setiap akad di lembaga ekonomi syariah tercantum sebuah klausul yang berbunyi, “ Jika salah satu pihak tidak menunaikan kewajibannya atau jika terjadi perselisihan di antara pihak-pihak terkait, maka penyelesaiannya dilakukan melalui Badan Arbitrase Syariah setelah tidak tercapai kesepakatan melalui musyawarah. Dengan amandemen ini maka klasul tersebut seharusnya dihapuskan dan seluruh format transaksi di bank dan lembaga keuangan syariah harus diubah.

Klausul tersebut juga terdapat pada Peraturan Bank Indonesia saat ini dan seluruh fatwa DSN MUI. Dalam fatwa DSN MUI dan PBI disebutkan, bahwa penyelesaian sengketa diselesaikan oleh Badan Arbitrase Syari'ah. Maka dengan amandemen ini, bunyi redaksi DSN MUI dan PBI yang menyebutkan peranan Badan Arbitrase seharusnya dihapus, karena telah ada Pengadilan Agama yang berwenang mengadilinya. Namun demikian, Badan Arbitrase tidak serta kehilangan peran, 
sebab jika para pihak memilih badan ini menyelesaikan kasusnya, maka hal itu dibenarkan. Pencantuman lembaga atbitrase syariah di fatwa DSN dan PBI untuk menyelesaikan sengketa syariah dapat dimaklumi, karena selama ini belum ada Undang-Undang No 3/2006. ${ }^{17}$

Akan tetapi, setelah Undang-Undang No3/2006 lahir, maka lembaga yang menyelesaikan kasus sengketa syariah tidak lagi monopoli lembaga arbitrase. Kecuali para pihak sejak awal memang sepakat memilih Lembaga Badan Abitrase.Klausul keharusan penyelesaian sengketa melalui lembaga arbitrase adalah sebuah kesalahan fatal. Sama fatalnya, jika setiap transaksi bisnis non syariah harus diselesaikan melalui lembaga arbitrase konvensional yang disebut BANI, bukan Pengadilan Umum.

Oleh karena itu, hal yang sama harus diterapkan juga di dalam bunyi kontrak syariah. Lima masukan dengan keluarnya UU No 3/2006, ada lima masukan kritis dan evaluatif yang perlu menjadi perhatian.Pertama, jika terjadi sengketa di bidang ekonomi syari'ah, penyelesaian perkaranya tidak boleh dibatasi (dikunci) hanya oleh lembaga arbitrase syariah (BASYARNAS). Sehubungan dengan itu bunyi klausul seluruh akad di lembaga keuangan syariah, bunyi fatwa DSN dan PBI yang mengharuskan penyelesaian sengketa dilakukan oleh badan Arbiotrase Syariah nasional, hendaknya dihilangkan. Kedua, Oleh karena seluruh perselisihan di bidang ekonomi syariah menjadi wewenang Peradilan Agama, maka seluruh hakim agama yang selama ini hanya memahami hukum-hukum keluarga (al-ahwal asy-syakhsyiah) perlu memahami hukum-hukum tentang perbankan dan lembaga keuangan syariah lainnya.

Untuk itu perlu dilaksanakan pelatihan dan workshop ekonomi syariah bagi hakim di lingkungan Peradilan Agama. Ikatan Ahli Ekonomi Islam Indonesia (IAEI) siap melakukannya bekerjasama dengan Mahkamah Agung untuk melakukan Workshop dan Training tersebut.Ketiga, Dalam RUU Perbankan Syariah dan RUU Surat Berharga Syariah Negara (SBSN) yang akan segera disahkan harus dimasukkan sebuah pasal yang menyebutkan, bahwa jika terjadi perselisihan dalam masalah perbankan syariah, harus diselesaikan di Peradilan Agama. Jadi bukan di pengadilan Umum atau Badan Arbitrase. DPR jangan sempat melupakan klausul ini agar kedua Undang-Undang tersebut sinkron dan tidak bertentangan.Keempat, dengan disahkannya UU No3/2006 ini, maka semua perundang-undangan yang terkait harus menyesuaikan (diamandemen), walaupun pasal yang diamendemen hanya satu pasal. Undang-Undang yang perlu dimandemen tersebut antara lain :

1. Undang-Undang Arbitrase,

2. Undang-Undang Pasar Modal,

3. Undang-Undang tentang Asuransi,

4. Undang-Undang tentang Pegadaian,

\footnotetext{
${ }^{17}$ Prides, Kompilasi Perundang-undangan tentang Ekonomi Syariah h. 2.
} 
5. Undang-Undang No 17/2000 tentang PPn, dsb.

6. Undang-Undang Resi Gudang, $\mathrm{dsb}^{18}$

Dalam UU N0 50/2009 menurut hemat penulis hampir tidak ada perbedaan yang substansial dengan UU N0 3/2006, oleh karena itu penulis tidak mengulasnya secara panjang lebar.

\section{KESIMPULAN}

Dari uraian sebelumnya, maka dapat disimpulkan sebagai berikut;

1. 1slam sebagai agama universal mampu mengakomodir segala permasalahan ummat Islam, termasuk ekonomi.

2. Eksistensi ekonomi syari'ah adalah sebagai wadah bagi siapa saja yang ingin terlibat dalam kegiatan ekonomi. Selain itu, eksistensi ekonomi syariah merupakan alternatif terhadap sistem ekonomi yang telah ada sebelumnya, yaitu sosialis dan kapitalis. Dan ia berbeda dengan sistem ekonomi yang lain.

3. Hakikat ekonomi syariah adalah ia merupakan salah satu dimensi dan konfigurasi dari Islam, yaitu muamalah. Ekonomi syariah memiliki ekspektasi yang berorentasi pada harmonisasi duniawi dan ukhrawi, sehingga dapat terwujud maqasid syariah yang tujuan Islam.

4. Eksistensi regulasai No 3/2006 dan No 50/2009 merupakan angin segar bagi praktisi ekonomi syariah secara khusus dan ummat Islam secara umum, olek karena regulasi tersebut memberikan kompetensi kepada Pengadilan Agama untuk menyelesaikan jika terjadi sengketa ekonomi syariah yang sebelumnya dilakukan oleh Pengadilan Negeri.

${ }^{18}$ Prides, Kompilasi Perundang-undangan tentang Ekonomi Syariah, h. 3. 


\section{Daftar Pustaka}

Antonio, Muhammad Syafi'I. Bank Syari'ah dari Teori ke Praktek .Cet. I; Jakarta: Gema Insani Press, 2001.

Agustianto, Peradilan dan Sengketa Ekonomi Syari'ah, . http :www. Nuriah. Com. (15 Juni 2010).

Bahri, Syaiful. Ekonomi Syari'ah dalam Sorotan. Jakarta: Permodalan Nasional Madani, 2003.

Chapra, Umar. Masa Depan Ilmu Ekonomi: Sebuah Tinjauan Islam Jakarta: Gema Insani Press, 2001.

Karim , Adiwarman. Ekonomi Mikro Islam. Jakarta: Rajawali Press, 2002.

Kahf, Monzer Ekonomi Islam: Telaah Analitik Terhadap Fungsi Sistem Ekonomi Islam .Yogyakarta: Pustaka Pelajar, 2005.

Lubis, Suhrawardi K. Hukum Ekonomi Islam, edisi I (Cet. II; Jakarta: Sinar Grafika, 2000.

Mas'ud,Ridwan dan Muhammad. Zakat dan Kemiskinan: Instrumen Pemberdayaan Ummat .Yogyakarta: UII Press, 2005.

Naqvi, Syed Nawab Haidir. Menggagas Ilmu Ekonomi Islam Yogyakarta: Pustaka Pelajar, 2003.

Prides, Kompilasi Perundang-undangan tentang Ekonomi Syariah .Cet. I; Ciputat: Gaung Persada Press, 2008.

Raharjo, Dawam. Ekonomi Islam: Suatu Kajian Kontemporer. Jakarta: Gema Insani Press, 2003.

Rahman, Afzalur. Doktin Ekonomi Islam .Yogyakarta: Simpul Rekacitra, 1995.

Saefuddin A.M., Studi Nilai-Nilai Sistem Ekonomi Islam (Cet. I; Jakarta: Media Da'wah, 1984. . Ontologi Sosial Ekonomi .Makassar: UMI Press, 1988 
